\title{
The Kohistan between Gilgit and Chilas, northern Pakistan: regional tectonic implications
}

\author{
T. Khan', M. A. Khan ${ }^{2}$, M.Q. Jan ${ }^{2}$ and M. Latif ${ }^{3}$ \\ ${ }^{\prime}$ Geoscience Laboratory, Geological Survey of Pakistan, Shahzad Town Islamabad, Pakistan \\ ${ }^{2}$ National Centre of Excellence in Geology, University of Peshawar, Pakistan \\ ${ }^{3}$ Northern Areas Directorate, Geological Survey of Pakistan, 84-H-8/1, Islamabad, Pakistan
}

\begin{abstract}
In this paper, we present geological description of an area located between Gilgit and Chilas within the Kohistan terrane. This terrane has been considered an intra-oceanic island arc, formed due to northward subduction of the Neo-tethyan lithospheric plate. At present, it is squeezed between the KarakoramAsian and Indian continental plates. Both the contacts are marked by suture zones, that is, Shyok (MKT) in the north and Indus (MMT) sutures in the south, respectively. The investigated area consists of plutonic, metamorphosed volcanic and sedimentary rocks, the Chilas Complex, and the Kamila Amphibolite. The metamorphosed volcanic and sedimentary rocks are packaged into the Jaglot Group. This group comprises basal turbiditic sediments, intercalated with amphibolites and calc-silicates (the Gilgit Formation), followed upward by the Gashu-Confluence Volcanics = Chalt Volcanic Group, and finally the Thelichi Formation = Yasin Group of Aptian-Albian age. The Thelichi Formation comprises a volcanic base (Majne volcanics) and overlying turbidites, local intercalation of marbles, volcaniclastics and lava flows. Greenschist and amphibolite facies are common in the Jaglot Group, and particularly the sillimanite in the Gilgit Formation. A pair of anticline (the Gilgit anticline) and syncline (the Jaglot syncline) make up the structural scenario. On the basis of field geology, we conclude that the entire Jaglot Group and its equivalents, the Yasin Group, Chalt Volcanic Group in Kohistan, and Burjila Formation, Bauma Harel Formation and Katzarah Formation in Ladakh show intra-oceanic back-arc basin rather than island arc affinities as suggested in the past.
\end{abstract}

\section{INTRODUCTION}

Northern area of Pakistan has been investigated in the past both in Kohistan and Ladakh regions (Desio, 1964, 1978, 1979; lvanac et al., 1956; Tahirkheli et al., 1979; Bard et al., 1980; Jan and Howie 1981; Coward et al., 1986; Petterson and Windley, 1991; Khan M. A. et al., 1989; Treloar et al., 1989; Ghazanfar et al., 1991; Virdi, 1992; Sullivan et al., 1993; Khan et al., 1994; Miller and Christensen, 1994). The high altitude area located between the Indus River, to the north of Chilas, and to the south of Gilgit has been thoroughly investigated (Khan et al., 1994). This area represents part of the Kohistan terrane that squeezed tectonically between the Shyok Suture or Main Karakoram Thrust (MKT), to the north and Indus Suture or Main Mantle Thrust (MMT), to the south (Fig. 1). This paper deals with some more field data related to the investigated area in a wider context that constrain the regional stratigraphic correlation to establish tectonic framework of the Kohistan region.

\section{OUTLINE OF GEOLOGY}

The Chilas Complex, Kohistan Batholith and Jaglot Group (Fig. 2) constitute mostly the entire part of the mapped area (Khan et al., 1994). However, the Kamila Amphibolite (Jan, 1977, 1990), and mafic dykes (Khan et al., 1992) are also exposed.

In the investigated area, southern part comprises the Chilas Complex, which includes mainly pyroxene quartz diorite and gabbro norites. However, all major rock types, reported elsewhere from the complex, are present in subordinate proportions (Jan et al., 1984; Khan et al., 1994). This complex has 


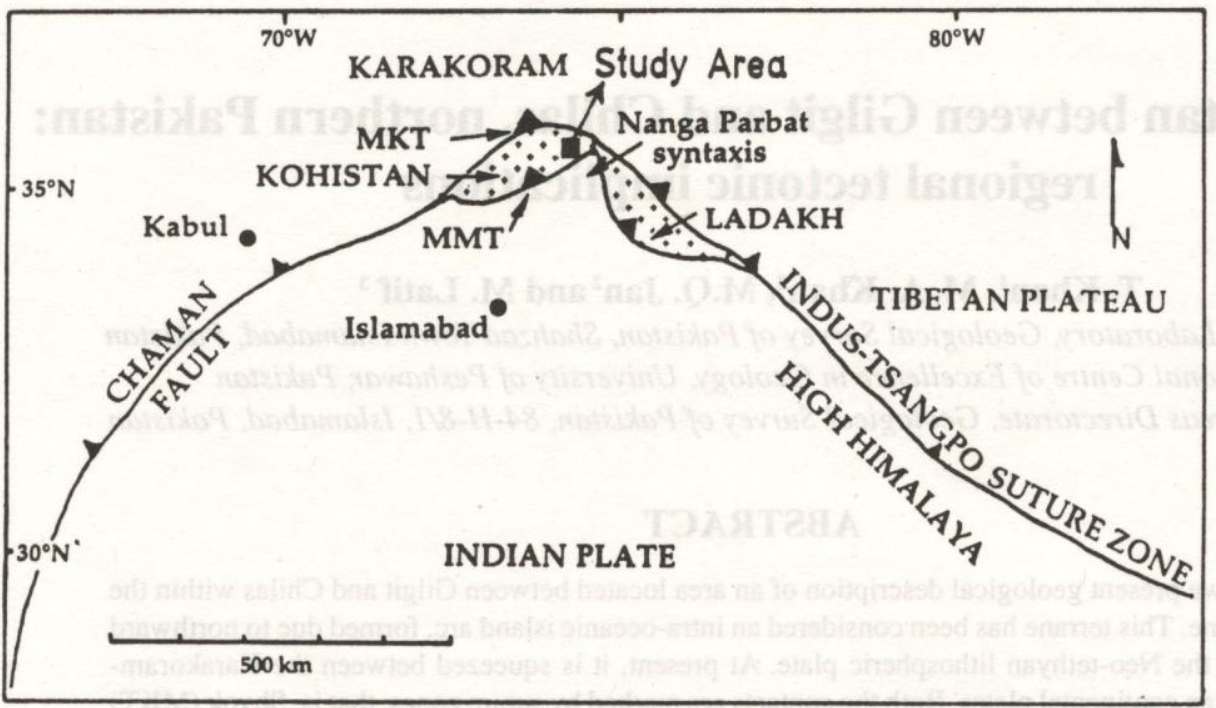

Fig. 1: Location map showing the study area in the regional tectonic framework. Legend: MKT=Main Karakoram Thrust, MMT=Main Mantle Thrust.

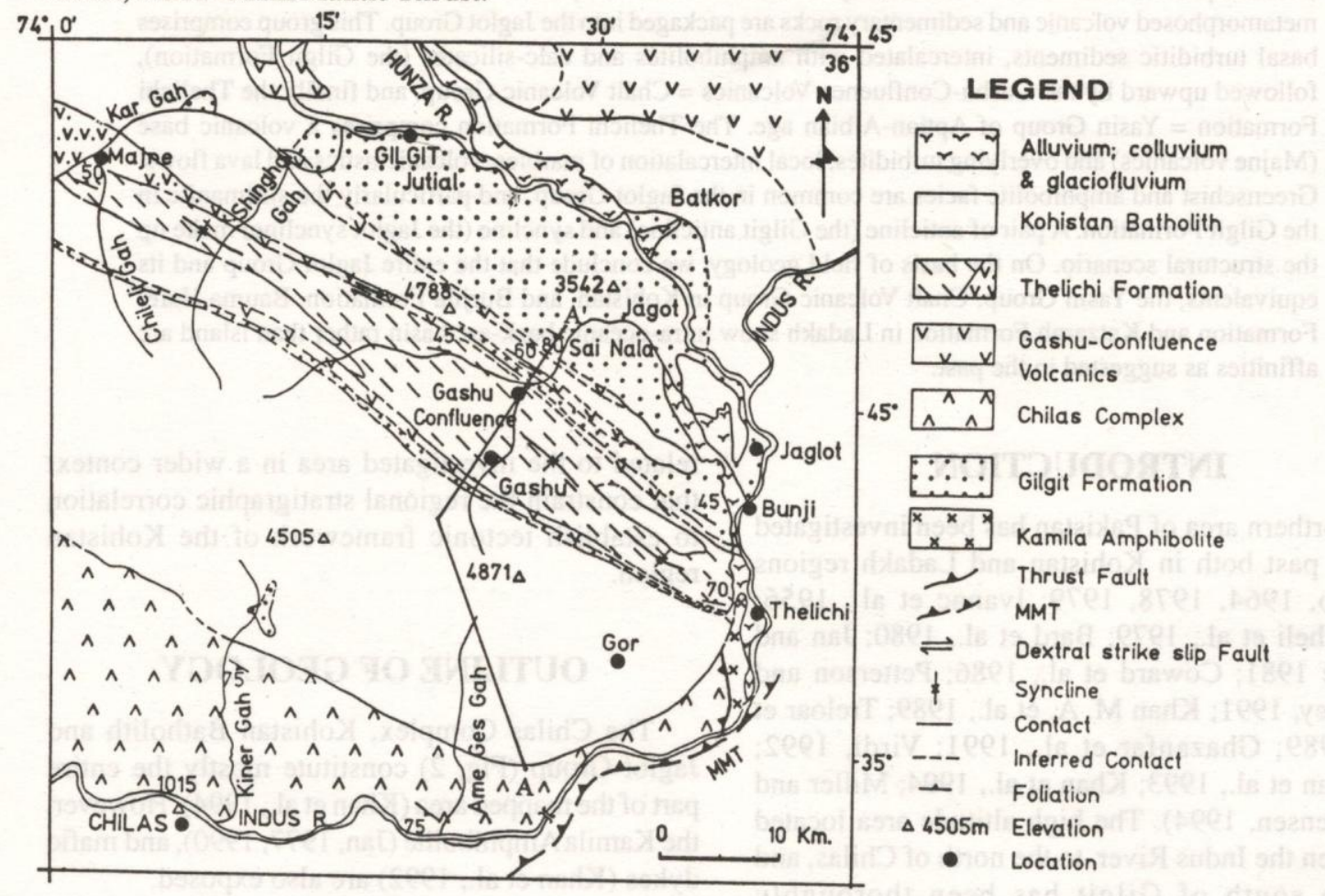

Fig. 2: GeologicaI map of the Kohistan terrane between Gilgit and Chilas (modified after Khan et al., 1994).

been intruded by the Kohistan Batholith which is the northwestern component of the Trans-Himalayan Batholith, extending for more than $2,700 \mathrm{~km}$ along the length of Himalaya and Karakoram (Petterson and Windley, 1985). Previously known as the Ladakh granodiorite (Ivanac et al., 1956), the batholith extends for $300 \mathrm{~km}$ x $50 \mathrm{~km}$ between Afghan border on the west and western flank of the Nanga Parbat 
The Kohistan between Gilgit and Chilas, northern Pakistan: regional tectonic implications

massif on the east (Tahirkheli and Jan, 1979). The Kohistan Batholith is the aggregate of multiphase plutonic activity ranging from $102 \mathrm{Ma}$ to $30 \mathrm{Ma}$ (Petterson and Windley, 1985). Here, in the mapped area, the batholith includes plutons of diorites, granodiorite, tonalite, trondhjemite and granites. Aplite and pegmatite are minor (Khan, 1994).

The Jaglot Group of metasedimentary and metavolcanic rocks is exposed in two NW-SE trending belts between the Gilgit River and the Gor drainage divide, separated by the Shinghai plutonic belt of the Kohistan Batholith (Khan et al., 1994). The SE extension is truncated against faults associated with the Main Mantle Thrust along the Indus River, whereas the NW extension is truncated due to intrusions of the Kohistan Batholith. The Jaglot Group includes in stratigraphic order, the Gilgit Formation, the Gashu-Confluence Volcanics and the Thelichi Formation (Fig. 3). A brief description of the individual formations of the Jaglot Group is outlined in this paper.

\section{Gilgit Formation}

The Gilgit Formation of Khan et al. (1994) includes paragneisses and schists, commonly interstratified at regular intervals. They are metapsammites and metapelites and trend in NWSE direction with steep dip either towards south or north, and attain an approximate thickness of $1 \mathrm{~km}$ (Fig. 3). These rocks are exposed in the vicinity of Gilgit, between Jaglot and Gilgit along the Karakoram Highway (KKH), Jutial Gah, Kar Gah and Sai Nala. Other rocks comprising the Gilgit Formation are the amphibolites and calc-silicate rocks.

The distribution of the Gilgit Formation is structurally controlled (Khan et al., 1994). Three NW-
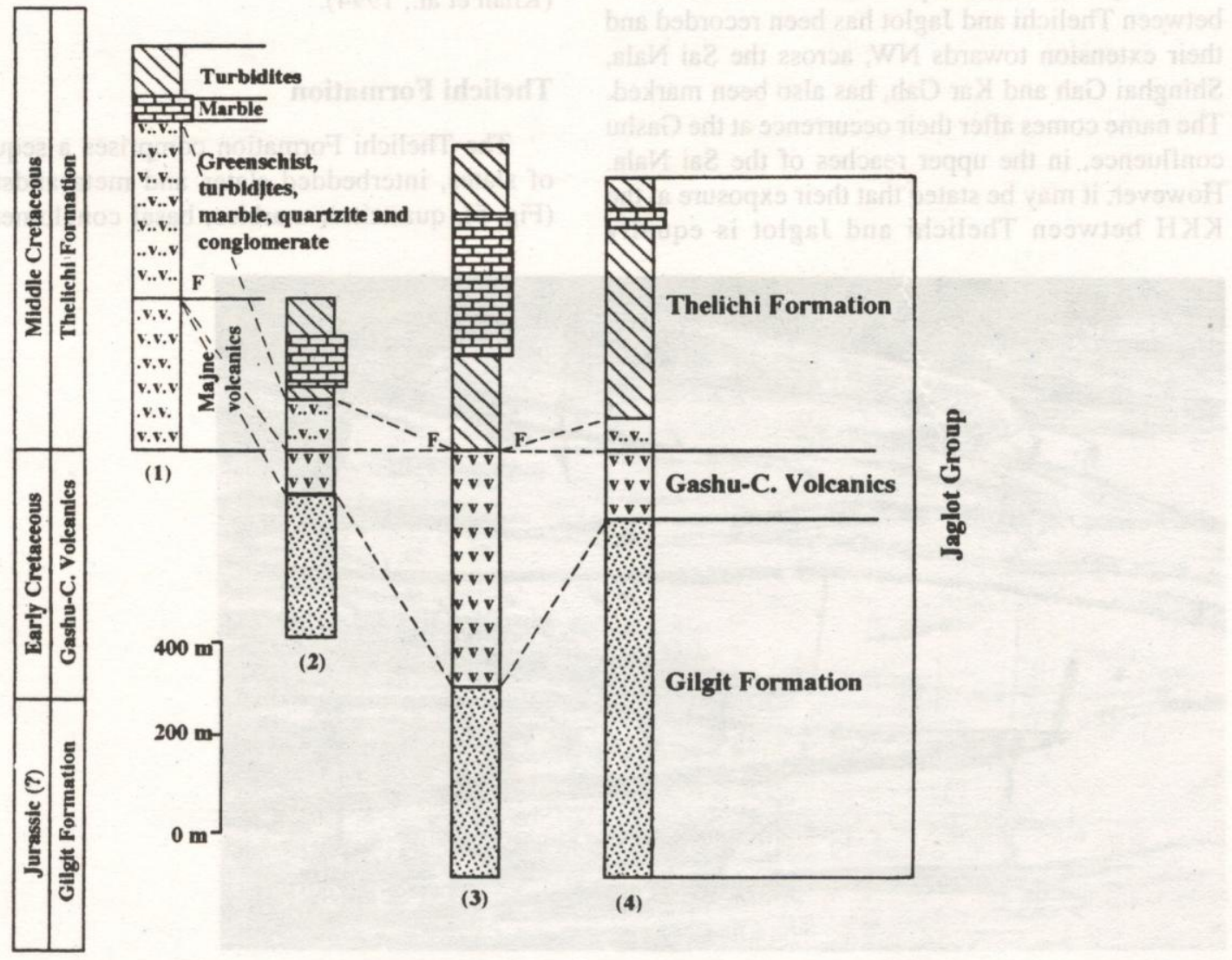

(3)

(4)

Fig. 3 Stratigraphy of the Jaglot Group in different parts of the mapped area (after Khan et al., 1994). (1) Chileli Gah, (2) Shinghai Gah, (3) Sai Nala, and Thelichi-Jaglot. 


\section{T. Khan et al.}

SE trending belts are mapped. The principle belt (15 $\mathrm{km} \mathrm{x} 40 \mathrm{~km}$ ) is located in the core of a large antiform (Coward et al., 1987). The other two belts are relatively narrower ( $<500 \mathrm{~m}$ each) and occupy the two limbs of the Jaglot syncline, enclosing younger strata of the Gashu-Confluence Volcanics and Thelichi Formation. This formation is overlain conformably by the GashuConfluence Volcanics. The lower contact is not clear, but presumably under-platted by the Chilas Complex (Khan et al., 1994). It is to be noted that the mineral assemblages in the schists and paragneisses of the Gilgit Formation varies from biotite, garnet, staurolite, up to kyanite and sillimanite. Migmatites are found only locally in the Sai Nala, and are regarded as the partial melting products of the paragneisses at the deeper levels.

\section{Gashu-Confluence Volcanics}

The presence of amphibolites on the roadside between Thelichi and Jaglot has been recorded and their extension towards NW, across the Sai Nala, Shinghai Gah and Kar Gah, has also been marked. The name comes after their occurrence at the Gashu confluence, in the upper reaches of the Sai Nala. However, it may be stated that their exposure at the $\mathrm{KKH}$ between Thelichi and Jaglot is equally important both in terms of complete lithology and intact stratigraphic position, which may be referred as a type section.

The Gashu-Confluence Volcanics consist of tuffs, volcaniclastic sediments and flows. An approximately $500 \mathrm{~m}$ thick section along the $\mathrm{KKH}$, south of Jaglot, comprises pillow basalts (Fig. 4) alternating with massive basalts and volcaniclastic sediments. The volcanics and associated rocks are metamorphosed to lower amphibolite facies. Their upper contact with the Thelichi Formation is sheared in the Thelichi-Jaglot area. However, persistence of the two formations along the contact suggests that originally the contact was stratigraphic. In other parts of the area, the contact relationship is not clear. But possibility of an unconformity may not be ruled out due to break in the grade of regional metamorphism between the two, i.e., the lower amphibolite/upper greenschist and greenschist facies, respectively (Khan et al., 1994).

\section{Thelichi Formation}

The Thelichi Formation comprises a sequence of slates, interbedded slates and metasandstones (Fig. 5), quartzites, marbles, basal conglomerates,
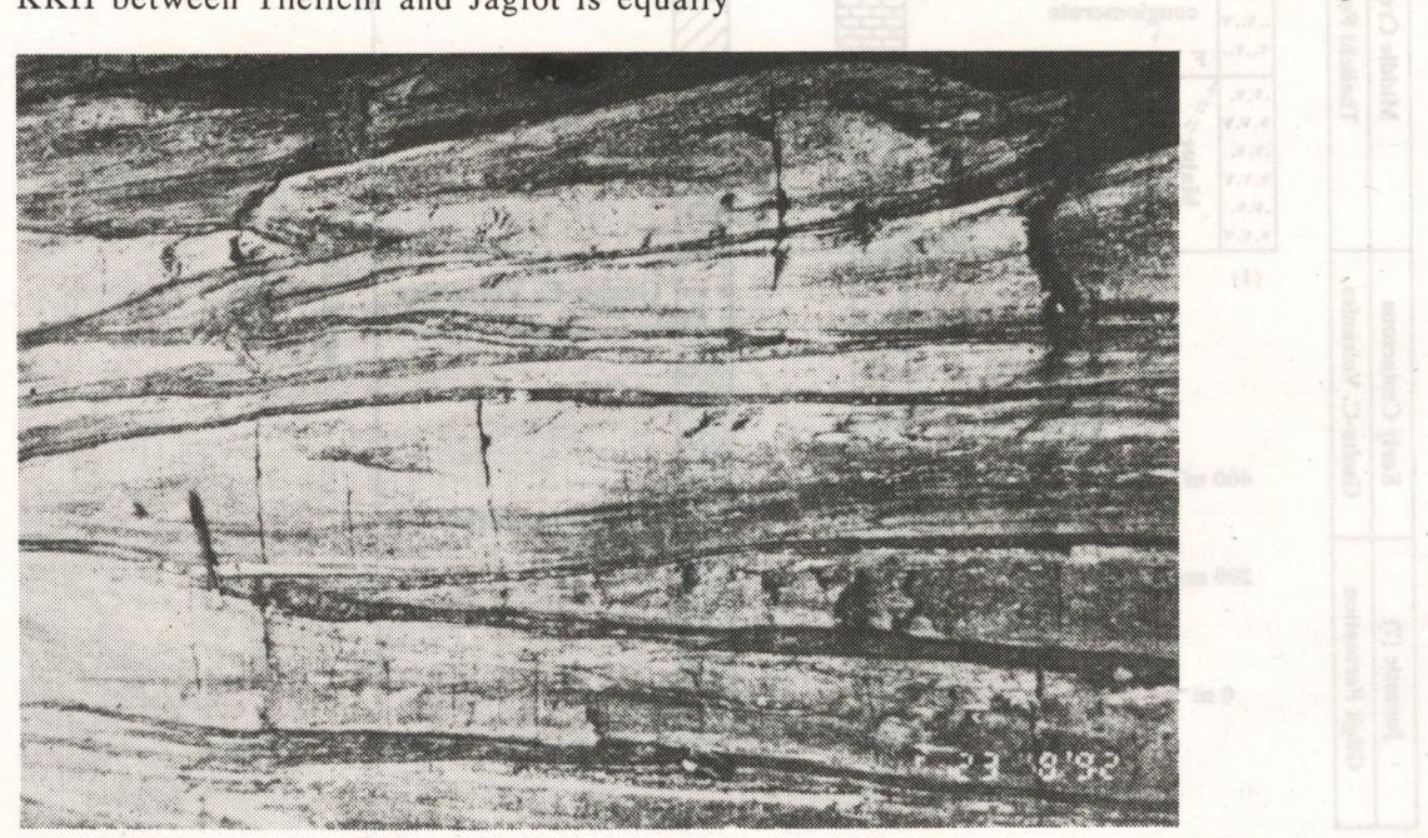

Fig. 4: Deformed pillows in metabasalt of the Gashu-Confluence Volcanics along KKH near Jaglot. Core of pillow is white and stretched dark part is the crust). 
The Kohistan between Gilgit and Chilas, northern Pakistan: regional tectonic implications

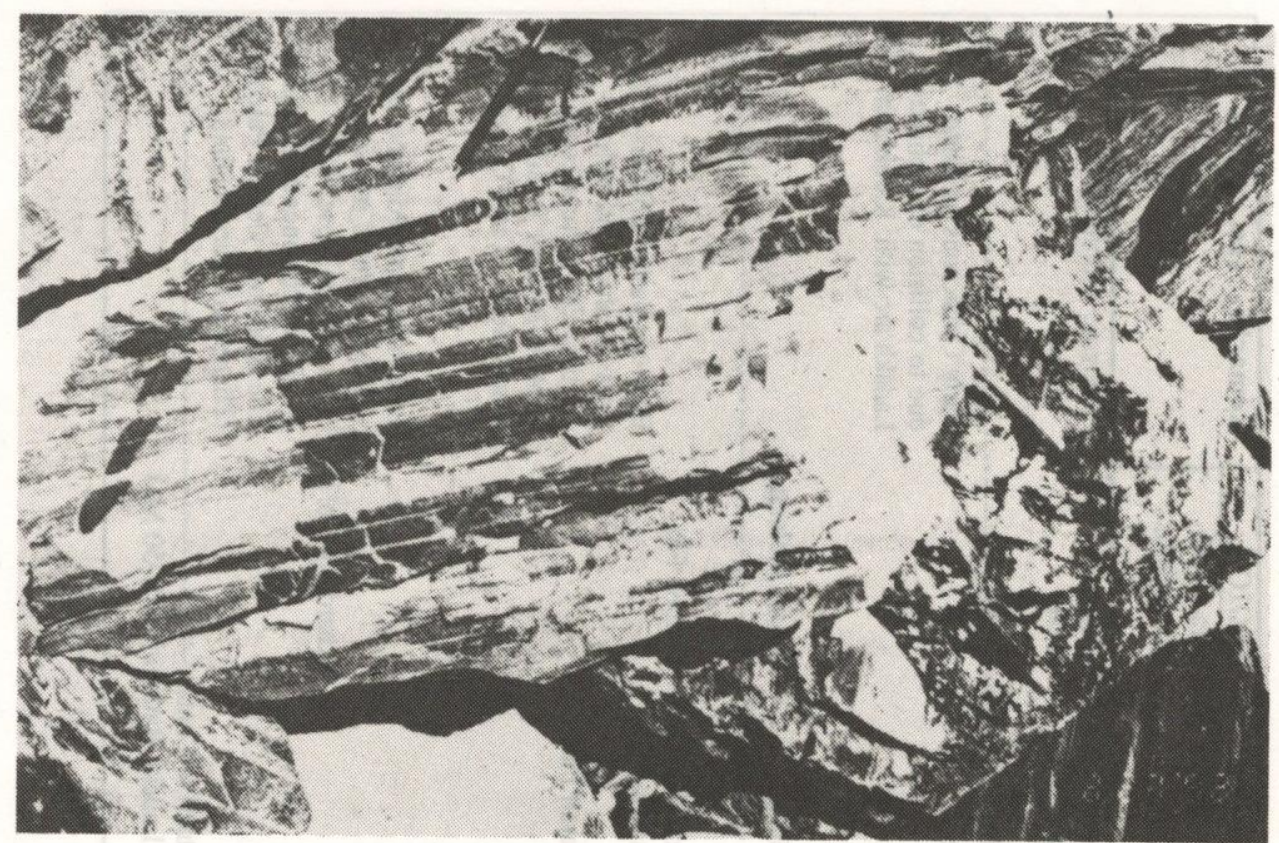

Fig. 5: A broken block of interbedded slate and metasandstone (turbidite) of the Thelichi Formation, Gashu Gah. (White part is metasandstone and the dark part slate).

pebbly slates, basic dykes and greenschists. In the Chelili area, slates are purplish or maroon in colour, underlain by granular grayish white marbles with an apparent thickness of $40 \mathrm{~m}$. The underlying greenschists are $400 \mathrm{~m}$ thick and contain 1-2 $\mathrm{m}$ thick intercalation of quartzitic and marble beds. The conglomerates contain pebbles of quartzites and marbles (minor) with calcite cement. These pebbles are elliptical in shape. In the pebbly slate, the pebbles are also quartzitic and rounded. In the Chelili Gah, the contact of this volcano-sedimentary unit is separated by a $5 \mathrm{~m}$ thick volcanic breccia and/or agglomeratic zone from the massive green volcanic body (Majne volcanics) which occurs in the upper reaches of Kar Gah, and as small lensoidal bodies in the Chileli Gah. These metavolcanics are fine grained and schistose to massive. In the Shinghai Gah area, the Majne volcanics either do not continue laterally, or are difficult to be distinguished from the underlying Gashu-Confluence Volcanics (Khan et al., 1994). The volcano-sedimentary sequence of the formation is also exposed in Shinghai Gah, except the presence of basal conglomerates and pebbly slates. At places, in Shinghai Gah, this formation contains clasts of granitic rocks embedded in greenschist (metavolcaniclastic) matrix. In the Sai
Nala area, the Thelichi Formation has the same major lithology (slates, interbedded slates, metasandstones, quartzites, marbles and greenschists) as those of the Shinghai Gah and Chileli Gah areas. These metasedimentary rock assemblages reflect the turbidite origin (Bouma sequence). Thick-bedded marbles occur in the middle part of the formation: This unit is laterally persistent and serves as a useful marker horizon. The succession of slates above and below the marble unit is almost indistinguishable.

The distribution of the Thelichi Formation is controlled by the Jaglot syncline. It occupies the core of the Jaglot syncline and is stratigraphically younger than the Gashu-Confluence Volcanics and the Gilgit Formation. The general trend of the formation is NW-SE and dips to the north and to south.

\section{REGIONAL STRATIGRAPHIC CORRELATION}

Similar compositional characters with that of the Jaglot Group are found sporadically from various parts of Kohistan (Table 1). To the north, Tahirkheli (1982) reported garnet-staurolite schists and 


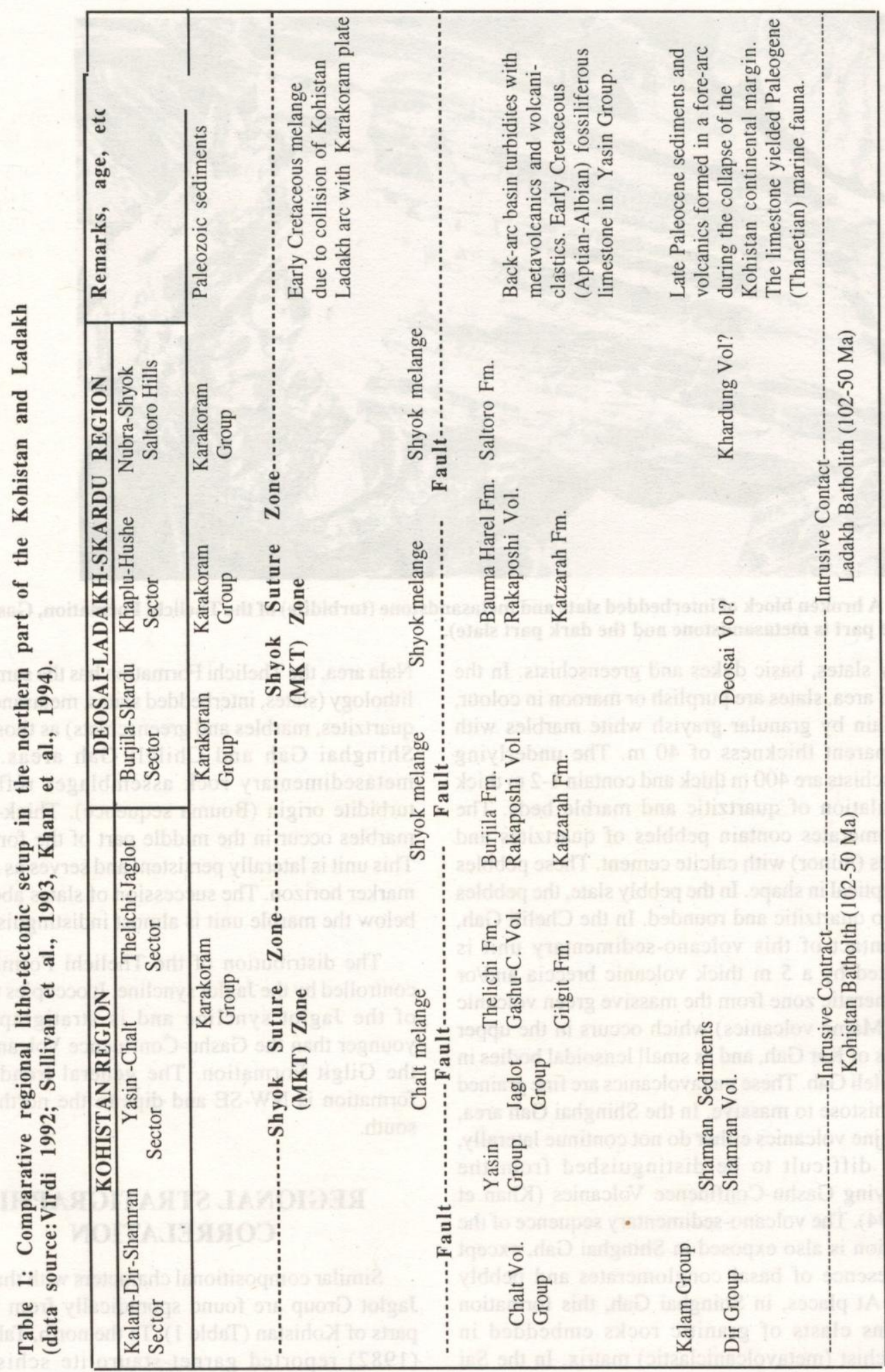


paragneisses from south of Mujaffarabad, Hunza valley. The stratigraphic position of these rocks i.e., below the Chalt Volcanic Group, is very similar to that of the Gilgit Formation. On the basis of structural analyses, the Gashu-Confluence Volcanics and the Thelichi Formation are the equivalents of the Chalt Volcanic Group and the Yasin Group, respectively. On regional levels, the Gilgit Formation resemble in lithology and stratigraphic position with the Katzarah Formation (Hanson, 1989). The Katzarah Formation comprises metasediments which are metamorphosed to garnet and sillimanite grades. It is overlain by the Rakaposhi Volcanic Complex and finally by the Bauma-Harel Formation (greenschist interbedded with slates, phyllites and minor carbonate layers with conglomerates).

Lithologies similar to those of the Thelichi Formation (i.e., turbidite sediments including sandsilt-, and mudstones, limestones, metavolcanics and volcaniclastic rocks) have been recognized in different areas of the Kohistan terrane, e.g., the Yasin Group in the Yasin and Hunza sectors (Ivanac et al., 1956; Pudsey, 1986; Tahirkheli, 1982), Burjila Formation from Burjila-Skardu and Khaplu-Hushe sectors (Desio, 1979; Tahirkheli, 1982) and BaumaHarel Formation in Skardu sector (Hanson, 1989). For instance, besides other lithologies, Pudsey (1986) reported basal conglomerates and granitic clasts from the Yasin area which are very much similar to the basal conglomerate and granitic clasts of the Thelichi Formation. Moreover, the maroon shales along the Shyok Suture or MKT in the Yasin and Drosh areas may be correlated with the pinkish or maroon slates found in the Thelichi Formation at Chelili Gah. These lithological similarities corroborate that this formation is the equivalent of the Yasin Group. The absence of fauna in the Thelichi Formation can only be attributed to the high-grade of metamorphism recorded in the rock assemblages. However, deformed-corals can be suspected in the Thelichi Formation at Shinghai Gah (Khan, T. et al., 1989), and the Yasin Group contain Aptian-Albian fauna (Hayden, 1916; Ivanac et al., 1956; Matsushita and Huzita, 1965; Pudsey, 1986).

\section{STRUCTURE}

The structure of the investigated area is governed by the Gilgit anticline and Jaglot syncline (Coward et al., 1986, 1987). The Gilgit Formation occupies core of the anticline. A-A' on Fig. 2 shows a simplified section across the fold structures (Fig. 6). In this section, the SW limb of the Gilgit anticline dips towards south in Jaglot and lower reaches of the Sai Nala. A major parasitic fold occurs in upper reaches of the Sai Nala, just to the north of the Gashu confluence. This not only repeats the Gilgit Formation and Gashu-Confluence Volcanics twice, but also changes the vergence towards SW. The Jaglot syncline is exposed at Thelichi and can be traced in the investigated area. It is a plunging fold with vergence towards SW. The fold axis trends $\mathrm{N} 50 \circ \mathrm{W}$ and plunges 30 towards SE. The Kohistan Batholith cuts the structures south of Majne in Chileli Gah. In the NW limb at the Gashu confluence, the Gashu-Confluence Volcanics are underlain by metasediments of the Thelichi Formation in an overturned sequence. The core of the syncline is occupied by interbedded slates and metasandstone units with a tight closure. A distinctive shear zone is present in the area, that is marked by abundant isoclinal folds and reverse faults. The GashuVolcanics and ultimately the paragneisses/schists of the Gilgit Formation reappear SW of Gashu village at SW limb of the Jaglot syncline. Further south, the structure is clearly cut by the Kohistan Batholith, diminishing any relationship between the Jaglot syncline and Chilas Complex (Khan et al., 1994).

\section{REGIONAL TECTONIC IMPLICATIONS}

The Indian plate is known to have experienced separation and northward movement from Gondwana continent in Cretaceous (Powell, 1979). It has also experienced a considerable increase in velocity gradient during the period from 80 to 53 $\mathrm{Ma}$ (Negi et al., 1986), and 150 to $130 \mathrm{Ma}$ age for drifting of Karakoram plate ahead of the Indian plate (Khan and Jan, 1991). Khan and Jan (1991) proposed that Karakoram plate was separated by the remnant Palaeo- or Meso-Tethys from the Eurasian plate and by the Neo-Tethys from the Indian plate. During this period an intra-oceanic Kohistan-Ladakh island arc was formed due to northward subduction of the NeoTethyan oceanic lithosphere (Tahirkheli and Jan 1979 and Honegger et al., 1982). This arc was subsequently welded to the Karakoram plate at the 


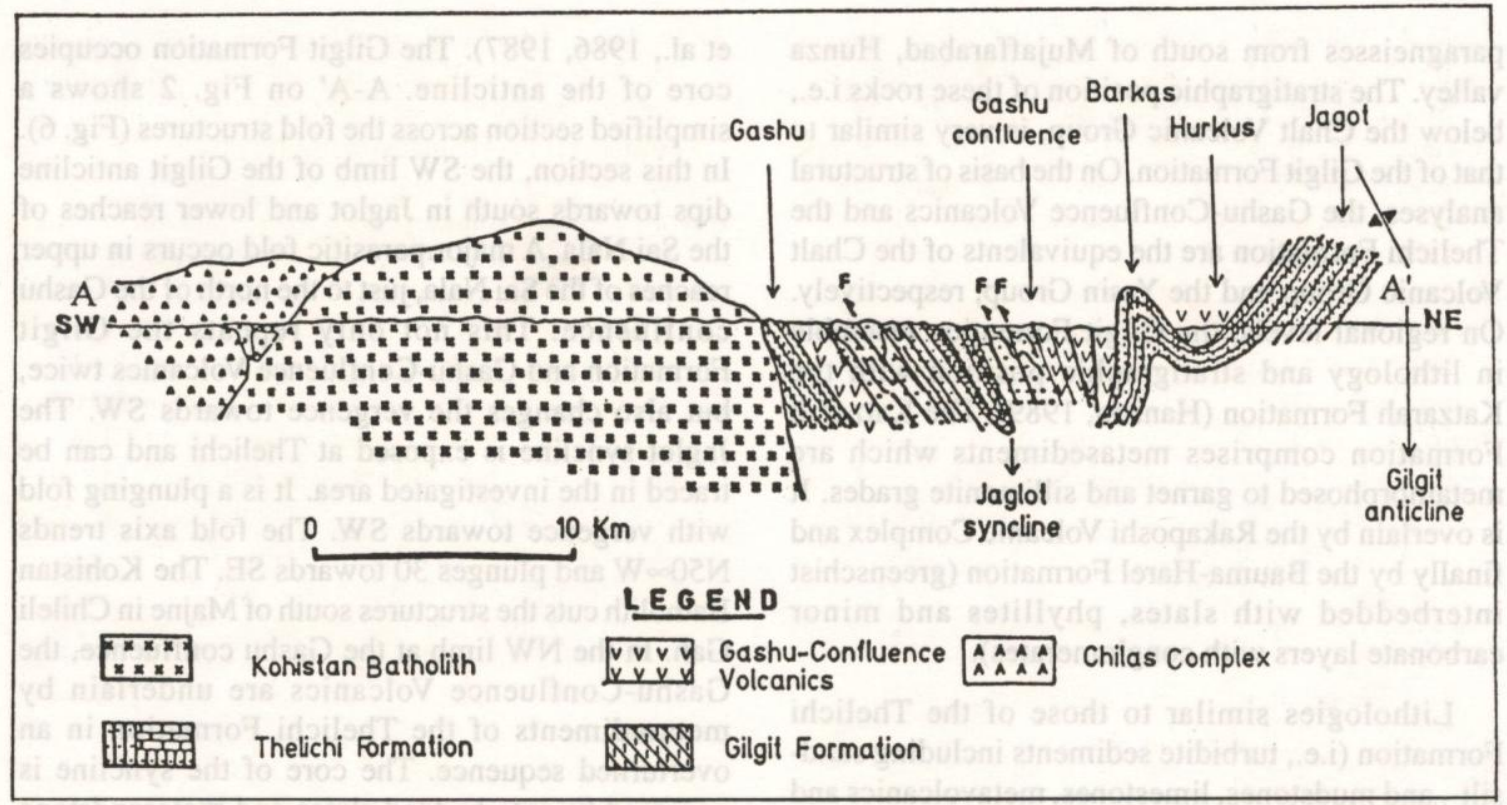

Fig.6: Structure characteristics of the rock units exposed between Gilgit and Chilas. Vertical scale is exaggerated.

site of Shyok (MKT) Suture (Petterson and Windley, 1985).

The geology of this high altitude area, located between Gilgit and Chilas presents new insights. For instance, the presence of a succession of metasediments and metavolcanics in central parts of Kohistan, e.g., South of Gilgit near Jaglot, comprises an intact stratigraphy that, from base to top, consists of the Gilgit Formation, the Gashu-Confluence Volcanics and the Thelichi Formation. Structurally, the Gilgit Formation occupies the core and the overlying succession, the southern limb of the Gilgit anticline. The Gashu-Confluence Volcanics and Thelichi Formation resemble the Chalt Volcanics and Yasin Group, exposed in the northern part of Kohistan near or along the Shyok Suture.

The implications for the broad tectonic evolution of Kohistan terrane are outlined in Khan et al. (1993, 1994). Features like intercalation between the metapelites and metapsammites, and preservations of grading relationship between the two lithologies suggest that the Gilgit Formation had a turbidite protolith before metamorphism. The metasediments of the Thelichi Formation are similar to the Bouma sequence, representing sand-, silt- and mudstones.
The Gashu-Confluence Volcanics (=Chalt Volcanic Group) are sandwiched in a turbidite succession suggesting that the entire Jaglot Group was deposited in an ocean basin rather than island arc setting, as suggested previously (Pudsey, 1986; Petterson and Windley, 1991). We believe that a large part of the Kohistan and Ladakh terrane in its northern parts comprises back-arc rather than island arc assemblages.

\section{ACKNOWLEDGMENTS}

The authors are deeply indebted to S.H. Gauhar and M. Sakhawat for providing field work facilities. T. Sherahase is thanked for reviewing this manuscript. Thanks are also extended to A. Habib and R. Anwar for helping in drawing the figures and typing the manuscript.

\section{REFERENCES}

Bard, J.P., Maluski, H., Matte, P. and Proust, F., 1980, The Kohistan sequence: crust and mantle of an obducted island arc. Geol. Bull. Univ. Peshawar, v. 13 (special issue), pp. 87-93.

Coward, M.P., Windley, B.F., Broughton, R.D., Luff, I.W., Petterson, M.G., Pudsey, C.G., Rex, D.C. and Khan, 


\section{The Kohistan between Gilgit and Chilas, northern Pakistan: regional tectonic implications}

M.A., 1986, Collision tectonics in the NW Himalayas. In: Coward and Ries (eds.), Collision Tectonics, Geol. Soc. London, v. 19 (special. publ.), pp. 203-219.

Coward, M.P., Butler, R.W.H., Khan, M.A. and Knipe, R.J., 1987, The tectonic history of Kohistan and its implications for Himalayan structure. Jour. Geol. Soc. London, v. 144, pp. 377-391.

Desio, A., 1964, Tectonic relationship between the Karakoram, Pamir and Hindukush, Report XXII Sess. India, Intern. Geol. Cong., New Delhi, v. 11, pp. 192-213.

Desio, A., 1978, On the geology of Deosio plateau (Kashmir). Mem. Acad. Naz., Leincei, v. 15, pp. 1-9.

Desio, A., 1979, Geological evolution of the Karakoram. In: Farah, A. and Dejong K. (eds.), Geodynamics of Pakistan. Geol. Surv. Pak., Quetta, pp. 111-124.

Ghazanfar, M., Chaudhry, M. N. and Hussain, M.S., 1991, Geology and petrotectonics of southeast Kohistan, northwest Himalaya, Pakistan Kashmir. Jour. Geol., v. $8 \& 9$, pp. 67-97.

Hanson, C.R., 1989, The northern suture in the Shigar valley, Baltistan, northern Pakistan. Geol. Soc. Am. Special paper, v. 232, pp. 203-215.

Hayden, H.H., 1916, Notes on the Geology of Chitral, Gilgit and Pamirs. Rec. Geol. Surv. Ind., v. 45, pp. 271-335.

Honegger, K., Dietrich, V., Frank, W., Gansser, A., Thoni, M. and Trommsdorff, V., 1982, Magnetism and metamorphism in the Ladakh Himalayas (the IndusTsangpo suture zone). Earth Planet. Sci. Lett., v. 60, pp. 253-292.

Ivanac, J.F., Traves, D.M. and King, D., 1956, The geology of the NW portion of the Gilgit Agency. Rec. Geol. Surv. Pak., Quetta, v. 3, pp. 1-27.

Jan, M.Q., 1977, Petrography of the amphibolites of Swat and Kohistan. Geol. Bull. Univ. Peshawar, v. 11, pp. 51-64.

Jan, M.Q., 1990, Petrology and geochemistry of the southern amphibolites of the Kohistan arc, N. Pakistan. In: Sharma, K.K. (ed.), Geology and geodynamic evolution of the Himalayan collision zone. Phys. \& Chem. Earth, v. 17, pp. 71-92.

Jan, M.Q. and Howie, R.A., 1981, The mineralogy and geochemistry of the metamorphosed basic and ultrabasic rocks of the Jijal Complex, Kohistan, N.W. Pakistan. Jour. Petrology, v. 22, pp. 85-126.

Jan, M.Q., Parvez, M.K., Khattak, M.U.K. and Windley, B.F., 1984, The Chilas stratiform complex: field and mineralogical aspects. Geol. Bull. Univ. Peshawar, v. 17 , pp. 153-169.

Khan, M.A. and Jan, M.Q., 1991, An interpretation of the Himalaya-Karakoram region of Pakistan in the light of plate tectonics and rock ages. Pak. Jour. of Geography, v. 1, pp. 1-23.
Khan, M.A., Jan, M.Q., Windley, B.F., Tarney, J. and Thirlwall, M.F., 1989, The Chilas ultramafic-mafic igneous complex of the Kohistan Island arc in the Himalaya of north Pakistan. Special paper, Geol. Soc. Am., v. 232, pp. 75-94.

Khan, T., 1994, Evolution of the "upper and middle crust in Kohistan island arc", Northern Pakistan. Unpubl. Ph.D. Thesis. Univ. Peshawar, 225p.

Khan, T., Khan, M.A. and Aziz, A., 1992, Petrogenetic comparison between the mafic dykes of Chilas complex and Kohistan batholith, Northern Pakistan. Acta Mineralogica Pakistanica, v. 6, pp. 118-125.

Khan, T., Khan, M.A. and Jan, M.Q., 1993, Kohistan, a collage of island arc and back-arc basin assemblages in the Himalaya of N. Pakistan. Abstracts with programs, Geol. Soc. Amer., v. A-122.

Khan, T., Khan, M.A., and Jan, M.Q., 1994, Geology of a part of the Kohistan terrane between Gilgit and Chilas, northern areas, Pakistan. Geol. Bull. Univ. Peshawar, v. 27 , pp. 99-112.

Khan, T., Latif, M., Khan, N.A. and Shah, S.H., 1989 , Geology and petrography of the rock outcrops in Shinghai Gah and Kiner Gah, Gilgit-Chilas districts, Northern Areas, Pakistan. Geol. Surv. Pakistan, I. R. No. 446

Matsushita, S. and Huzita, K., 1965, Geology of Karakoram and Hindukush. Kyoto University, Japan, 150 p.

Miller, D.J., and Cristensen, N.I., 1994, Seismic signature and geochemistry of an island arc: A multidisciplinary study of the Kohistan accreted terrane, northern Pakistan. Jour. Geophy. Res., v. 99(WO B6), pp. 11,623-11,624.

Negi, J.G., Pandey, O.P. and Agrawal, P.K., 1986, Supermobility of hot Indian Lithosphere. Tectonophysics, v. 131, pp. 147-156.

Petterson, M.G. and Windley, B.F., 1985, Rb-Sr dating of the Kohistan arc batholith in the Transhimalayan of the North Pakistan and tectonic implications. Earth Planet. Sci. Lett., v. 74, pp. 45-57.

Petterson, M.G., Windley, B.F. and Luff, I.W., 1990. The Chalt volcanics, Kohistan, N. Pakistan. High-Mg tholeiites and low Mg calc-alkaline volcanism in a Cretaceous island arc. In: K.K Sharma (ed.) Geology and geodynamic evolution of the Himalayan collision zone. Phys. \& Chem. Earth, v. 17, pp. 19-30.

Petterson, M.G. and Windley, B.F., 1991, Changing source regions of magmas and crustal growth in the TransHimalayas: Evidence from the Chalt volcanics and Kohistan batholith, Kohistan, N. Pakistan. Earth Planet. Sci. Lett., v. 102, pp. 326-341.

Powell, C.McA., 1979, A speculative tectonic history of Pakistan and surroundings: some constraints from Indian ocean. In: Farah, A., and Dejong K. (eds.), Geodynamics of Pakistan. Geol. .Surv. Pak., Quetta, pp. 5-24. 


\section{T. Khan et al.}

Pudsey, C.J., 1986, The Northern Suture, Pakistan: margin of a Cretaceous island arc. Geol. Mag., v. 123, pp. 405- 423.

Pudsey, C.J., Coward, M.P., Luff, I.W., Shackleton, R.M., Windley, B.F. and Jan, M.Q., 1985, The collision zone between the Kohistan arc and the Asian plate in NW Pakistan. Trans. R. Soc., Edinb., v. 76, pp. 464-479.

Sullivan, M.A., Windley, B.F., Saunders, A.D., Haynes, J.R. and Rex, D.C., 1993, A palaeogeographic reconstruction of the Dir Group: evidence for magmatic arc migration within Kohistan, N. Pakistan. In: Treloar, P.J., and Searle, M.P. (eds.), Himalaya Tectonics, Geol. Soc. London, Special pub., v. 74, pp. 139-160.

Tahirkheli, R.A.K., 1982, Geology of Himalaya, Karakoram and Hindukush in Pakistan. Geol. Bull. Univ. Peshawar, pp. 15-54.

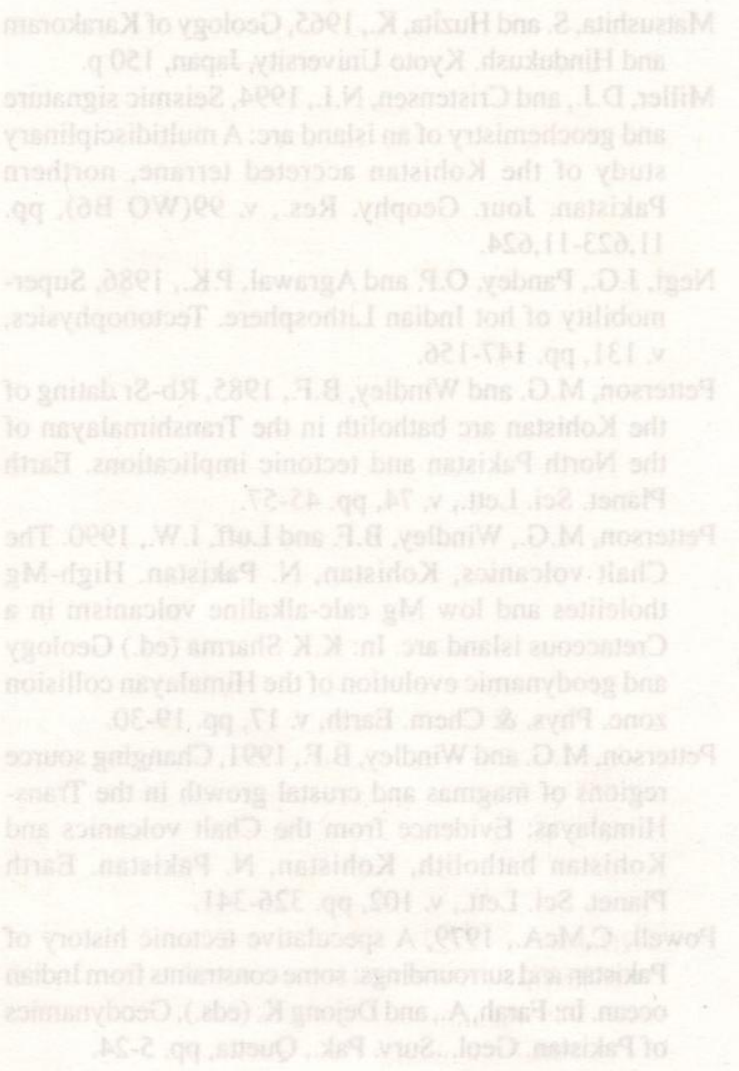

Tahirkheli, R.A.K. and Jan, M.Q., 1979, Geology of Kohistan, Karakoram, Himalaya, Northern Pakistan. Geol. Bull. Univ. Peshawar, v. 11(special issue).

Treloar, P.J., Rex, F.C., Guise, P.G., Coward, M.P., Searle, M.P., Windley, B.F., Petterson, M.G., Jan, M.Q. and Luff, I.W., 1989, K-Ar and Ar-Ar geochronology of the Himalayan collision in NW Pakistan: constraints on the timing of suturing, deformation, metamorphism and uplift. Tectonics, v. 8, pp. 881-909.

Virdi, N.S., 1992, Cretaceous marginal basins of the IndusKohistan Collision Zone - development and evolution. In: Sinha, A. K. (ed.), Himalayan Orogen and Global Tectonics, pp. 157-168. 